\author{
Animal Review \\ 2017 Vol. 4, No. 4, pp. 53-57 \\ $\operatorname{ISSN}(e): 2409-6490$ \\ $\operatorname{ISSN}(p): 2412-3382$ \\ DOI: 10.18488/journal.ar.2017.44.53.57 \\ (C) 2017 Conscientia Beam. All Rights Reserved. \\ (i) Check for updates
}

\title{
COMPETENCY ASSESSMENT OF VETERINARY MEDICINE STUDENTS WHO ARE TRAINED IN BASRA VETERINARY HOSPITAL - 2017
}

\author{
Mudhar A. S. Abu
} Tabeekh ${ }^{1}$

\author{
'Basra Veterinary Hospital, Basra, Iraq \\ Email:mudhar_64@yahoo.com
}



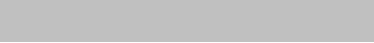

Article History

Received: 1 January 2018 Revised: 16 January 2018 Accepted: 19 January 2018 Published: 22 January 2018

\section{Keywords}

Basra hospital

Competency assessment

Veterinary students.

\begin{abstract}
This study designated to evaluate the competency of veterinary students who are trained in Basra Veterinary Hospital-Basra governorate- Iraq. In the student life, performance evaluations should revealed areas of excellence. Very little research has considered in training evaluation in a veterinary sciences. The test was carried out by the students of the Veterinary Medicine College- Basra University from the third and fourth stages who succeeded to the fourth and fifth stages. One hundred and two students participated in the performance evaluation, 47 students from the fourth stage and 55 from the third stage. Totally, there were 100 multiple questions presented to the participants. The questions included 13 aspects of veterinary sciences disciplines. The results of this study revealed that the evaluation of the competency of veterinary students in the fourth stage was higher compared to the third stage by comparing the percentage of correct answers for both groups (65.86 and 60.95) respectively. In addition, the two groups recorded high percentage in physiology correct answers and low percentage in animal hygiene for the fourth year students and infectious diseases for the third year.
\end{abstract}

Contribution/Originality: Very little research has considered in training evaluation in a veterinary sciences. This study contributes to the educational literature by assessing the level of the trainee students using the method of direct questioning, which represents a good method in evaluating the veterinary performance to improve skills of veterinary undergraduates.

\section{INTRODUCTION}

The word competence be used to describe the attribute and ability of the person and competency as the skill itself [1]. In-training evaluations are a common but highly criticized method of assessing the competency of veterinary students completing training. They involve assessment of on-going performance in the workplace, performed by the supervisor. They are highly feasible and one of the few ways that a student's performance in an authentic context can be evaluated [2]. However, veterinary competency is not easy to assess. It is complex, context dependent, and partly involves skills and attitudes that are not observable. It is also not well defined. Frequently definitions are locally created, and are supported more often by expert and stakeholder opinion than empirical research [3]. Veterinary competency encompasses cognitive aspects of formal and tacit discipline knowledge, problem solving abilities, and clinical judgment; functional aspects of veterinary-specific technical skills and generic skills such as record keeping; and social aspects such as communication, interpersonal skills, and 
personal and professional behaviours and attitudes. Overarching these are metacompetencies that enable students to acquire and grow in competency and to mobilise and combine different dimensions of competency in a way appropriate for the context [4]. Assessing learners in natural settings offers the opportunity to see beyond what they know and into what they actually do, which is fundamentally essential to training qualified physicians. Residents and students report rarely being observed during their educational process, even though they value the experience. Reasons for this include a lack of faculty time, a lack of faculty skills, a potential stressful effect on the learner, and a perceived lack of validation of the assessment [5].

During 2017, the veterinary hospital in Basra provided many veterinary services. Developing the scientific and practical skills of the students is of great importance so that future veterinarians can perform their duties through implementing the treatment and vaccination plan. Competency is thus of central importance to both the education of veterinarians and their initial and continued certification to practice [2]. The study aimed to investigate the development of veterinary skills of veterinary undergraduates and describes the evaluation of summer training intended to enhance students' performance on their veterinary knowledge.

\section{MATERIALS AND METHODS}

This study was conducted in the veterinary hospital headquarter in Basra governorate. The study reported here investigates the reliability and validity of a standardized evaluation form used to assess students' knowledge, clinical skills and professionalism during the summer training for fourth and third stage students of veterinary medicine college- Basra University who succeeded to the fourth and fifth stages. One hundred and two students participated in the veterinary competence test, 47 students from the fourth stage and 55 from the third stage.

The assessment of veterinary competence was conducted through direct questions to all students. Totally, there were 100 multiple questions presented to the participants as PowerPoint presentation. The participants allowed to answer these questions within a period of 30 seconds on paper prepared for this purpose. The participants names were recorded and the test papers were collected and corrected. The questions included 13 aspects of veterinary sciences disciplines such as: Infectious disease, Animal hygiene, Internal medicine, Anatomy, Physiology, Nutrition, Surgery, Pharmacology, Parasitology, Fertility and Parturition, Microbiology, Histology and Poultry diseases. The marks of the test papers after corrections have been analyzed in charts. The percentages of true answers were classified according to participants categories, as well as according to different veterinary sciences.

\section{RESULTS AND DISCUSSION}

One of the main strategic objectives of the World Organization for Animal Health (OIE) is the continual development of up-to-date standards and guidelines for the management of Veterinary Services and their components [6]. Monitoring a student's progress towards achieving the necessary knowledge, skills, and attitudes for day one competency, and then certifying their achievement of it, is important to the student, so their learning is appropriately directed, but also important to ensure the safety of the public, the welfare of animals [2]. Workplacebased assessment is often used as a general term describing a variety of methods of assessment that use ratings, including in-training evaluation [7, 8]. However, some authors do not include in-training evaluation as a type of workplace-based assessment [9].

The results of the veterinary competence assessment 2017 as showed in Fig 1, reported that the results of the fourth stage were higher than the third (65.86 and 60.95) respectively. In a simple comparison of the results of this study with the results recorded in previous year, we note that the results recorded in 2016 for the fourth and third stage students according to Abu [10] in the test of performance appraisal of veterinarians, were higher than the results of the current year (71.03 and 62.46) respectively. On the other hand, the results of 2017 were higher than those recorded in 2015 by Abu [11] which were (62.26 and 56.80) respectively. 


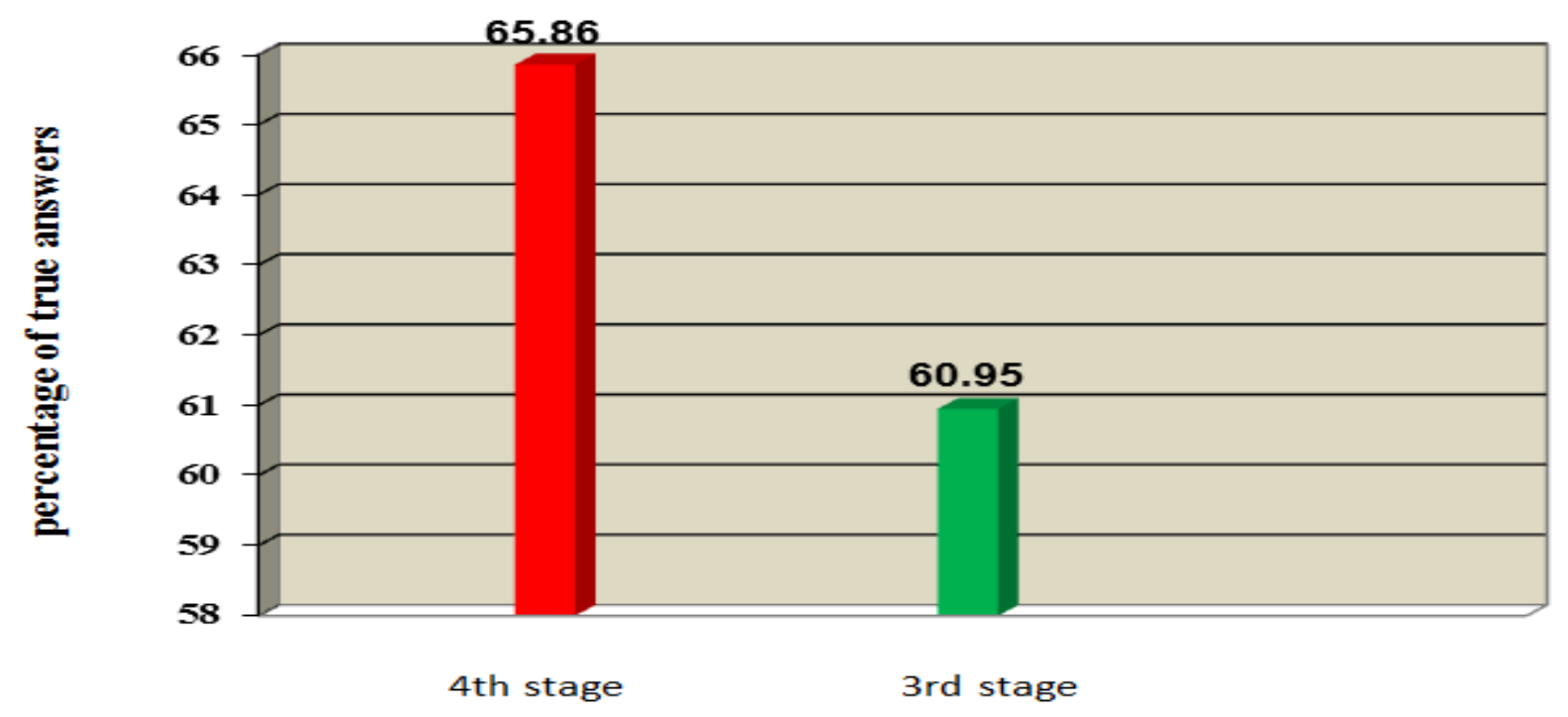

participants categories

Fig-1. The percentage of correct answers according to participants categories Source: Table was constitute from analyzed data of current study

The students of forth stage were become more familiar in veterinary sciences and practice through their exercise in the hospital, where they came in contact with field work in animal husbandry and treatment. The low percentage of correct answers of $3^{\text {rd }}$ year students referred to the lack of knowledge in the diagnosis of microbial agents and the treatment of diseases and this result may be due to inadequate field experiences.

The findings of the current study as in Fig. 2, showed that the percentage of correct answers of 4th year veterinary students was higher in compare to $3 \mathrm{rd}$ year students. The best results of the $4^{\text {th }}$ year and $3^{\text {rd }}$ students were recorded in Physiology (80.39 and 78.18) respectively, while low percentages of correct answers was recorded for the $4^{\text {th }}$ year students in Animal Hygiene 47.44 and for the $3^{\text {rd }}$ students in Infectious Diseases 44.65. According to Fig. 2, the percentage of correct answers of $4^{\text {th }}$ year students in the other veterinary sciences were: Internal Medicine 68.23, Histology 68.08, Poultry Diseases 59.84, Surgery 70.97, Fertility and Parturition 56.11, Pharmacology 67.62, Microbiology 65.95, Parasitology 66.22, Nutrition 72.60, Anatomy 71.40 and infectious diseases 54.25. For the $3^{\text {rd }}$ year students, the percentage of correct answers were: Internal Medicine 57.01, Histology 62.84, Poultry Diseases 51.47, Surgery 58.83, Fertility and Parturition 52.61, Pharmacology 61.03, Microbiology 62.84, Parasitology 66.13, Nutrition 75.11, Anatomy 66.81 and in Animal Hygiene 56.25. The $4^{\text {th }}$ students were more superior students from the third year which might be due to the progression of the knowled ge in the veterinary disciplines gained via their study and experiences. In addition $4^{\text {th }}$ student gained a good experiences through the summer training when practiced at the veterinary hospital.

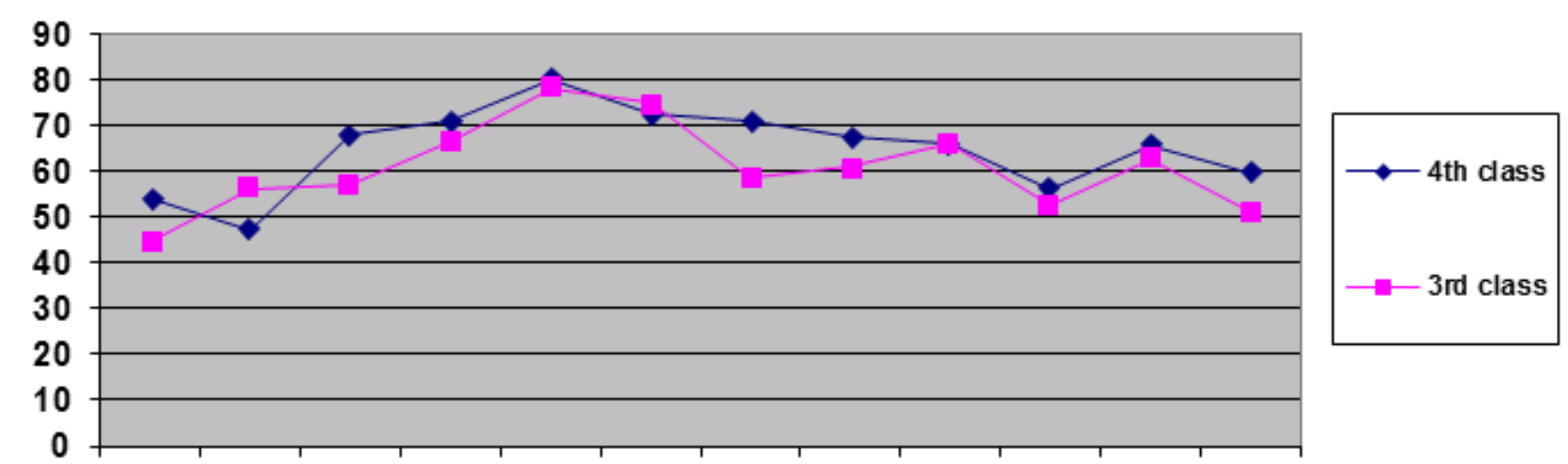

inf. Hyg. Med. Anat. Phys. Nut. Surg. Phar. Para. Fert. Mic. Poult.

Fig-2. The percentage of correct answers of $4^{\text {th }}$ and $3^{\text {rd }}$ year students according to the veterinary sciences Source: Table was constitute from analyzed data of current study 
The competence evaluation revealed a clear idea to the deanship of the college of veterinary medicine to know the ability of their students in different veterinary disciplines and trying to improve the weakness in the educational curriculum. Recent studies of veterinary practices and services have suggested that more attention must be focused on business practices and on the skills, knowledge, and abilities of veterinarians related to veterinary practice management [12]. So, there is a need for more research on assessment of veterinary competence in veterinary medical education.

An example from a medical school, Henry and Mavis [13] discussed how their institution's evaluations were insufficient for answering new and important questions that go beyond traditional cognitive measures: specifically, no data set was available that allowed the institution to answer questions about practice environment and curricular innovations. More recently, institutions have become interested in learning to what extent their broad missions are accomplished or not. Similarly, academic leaders are not simply interested in performance of learners on tests of competence; they want to know more about how their graduates are doing in the practice setting. To answer questions such as these, educators must expand their systems of evaluations to address these broader themes.

\section{CONCLUSION}

The findings give insights into the process of judgment of competency by veterinary supervisors that will inform further research. One of the most desired purpose of this is to argue why educators should design more effective systems of evaluation that are responsive to the needs of educational program planning. The evaluation, encourage the academic staff of the college of veterinary medicine to recognized the strength and the weakness in the veterinary medical education and trying to improve the learning of veterinary curriculum.

Funding: This study received no specific financial support.
Competing Interests: The author declares that there are no conflicts of interests regarding the
publication of this paper.
Contributors/Acknowledgement: The author would like to thank and appreciate the veterinary
directorate represented by its general manager because of the continuous support and encourages in the
development of skills of veterinary staff. Many thanks and respect to the director of veterinary hospital in
Basra, enable us to conduct the evaluation, and finally a great respect to everyone who gave a help in
performing this study especially all the participants categories.

\section{REFERENCES}

[1] K. Khan and S. Ramachandran, "Conceptual framework for performance assessment: Competency, competence and performance in the context of assessments in healthcare--deciphering the terminology," Medical Teacher, vol. 34, pp. 920-928, 2012. View at Google Scholar | View at Publisher

[2] E. J. Norman, "Judging competency a study of in-training evaluation of veterinary students," PhD Thesis, Massey University, Manawatu, New Zealand, 2016.

[3] M. A. Cake, M. A. Bell, J. Williams, F. Brown, M. Dozier, S. M. Rhind, and S. Baillie, "Which professional (nontechnical) competencies are most important to the success of graduate veterinarians? A best evidence medical education (BEME) systematic review: BEME guide no. 38," Medical Teacher, vol. 38, pp. 550-563, 2016. View at Google Scholar | View at Publisher

[4] N. Fernandez, V. Dory, L. G. Ste-Marie, M. Chaput, B. Charlin, and A. Boucher, "Varying conceptions of competence: An analysis of how health sciences educators define competence," Medical Education, vol. 46, pp. 357-365, 2012. View at Google Scholar | View at Publisher

[5] H. B. Fromme, R. Karani, and S. M. Downing, "Direct observation in medical education: A review of the literature and evidence for validity," Mount Sinai Journal of Medicine, vol. 76, pp. 365-37 1, 2009. View at Google Scholar | View at Publisher

[6] OIE, "OIE's sixth strategic plan for the period 2016 - 2020," presented at the 83rd General Session World Assembly, Paris, 24-29 May, 2015. 
[7] K. W. Eva, G. Bordage, C. Campbell, R. Galbraith, S. Ginsburg, E. Holmboe, and G. Regehr, "Towards a program of assessment for health professionals: From training into practice," Advances in Health Sciences Education, vol. 21, pp. 897913, 2016. View at Google Scholar | View at Publisher

[8] C. A. Weijs, J. B. Coe, and K. G. Hecker, "Final-year students' and clinical instructors' experience of workplace-based assessments used in a small-animal primary-veterinary-care clinical rotation," Journal of Veterinary Medical Education, vol. 42, pp. 382-392, 2016. View at Google Scholar | View at Publisher

[9] J. Massie and J. M. Ali, "Workplace-based assessment: A review of user perceptions and strategies to address the identified shortcomings," Advances in Health Sciences Education, vol. 21, pp. 455-473, 2016. View at Google Scholar $\mid$ View at Publisher

[10] T. M. A. S. Abu, "The performance appraisal of veterinarians in Basra veterinary hospital- Basra governorate/ Iraq," International Journal of Information Research and Review, vol. 03, pp. 2960-2962, 2016.

[11] T. M. A. S. Abu, "The performance appraisal of veterinarians in different veterinary clinics in Basra governorate/Iraq," Mirror of Research in Veterinary Sciences and Animals, vol. 4, pp. 17-24, 2015.

[12] D. R. Ilgen, "Skills, knowledge, aptitudes, and interests for veterinary practice management: Fitting personal characteristics to situational demands," Journal of Veterinary Medical Education, vol. 29, pp. 153-156, 2002. View at Google Scholar | View at Publisher

[13] R. C. Henry and B. E. Mavis, "A strategy for developing educational evaluations for learner, course, and institutional goals," Journal of Veterinary Medical Education, vol. 29, pp. 147-152, 2002. View at Google Scholar | View at Publisher 